\title{
Inequalities in the spatial concentration of agricultural crops among the micro- and mesoregions of Minas Gerais, Brazil
}

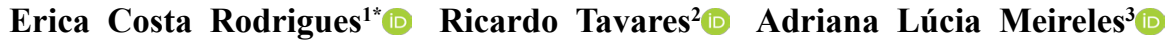

\author{
${ }^{1}$ Programa de Pós-Graduação em Saúde e Nutrição, Universidade Federal de Ouro Preto (UFOP), 35400-000, Ouro Preto, MG, Brasil. E-mail: \\ ericacrodrigues2003@yahoo.com.br. "Corresponding author. \\ ${ }^{2}$ Departamento Estatística, Universidade Federal de Ouro Preto (UFOP), Ouro Preto, MG, Brasil. \\ ${ }^{3}$ Departamento de Nutrição Clínica e Social, Universidade Federal de Ouro Preto (UFOP), Ouro Preto, MG, Brasil.
}

\begin{abstract}
The present research aimed to map and estimate the spatial autocorrelation of agricultural crops of coffee, corn, soybeans, sugarcane and beans in the state of Minas Gerais and analyzed in the period from 2011 to 2015. The planted area data were obtained of the Systematic Survey of Agricultural Production - IBGE. The Exploratory Spatial Data Analysis model was used to calculate spatial autocorrelation using the Global and Local Moran Index. Significant spatial self-correction was reported in all studied cultures (P-value $<0.05)$. The regions with the highest concentration of planted area are located in the western portion of the state. The least significant planting regions were the municipalities located in the Jequitinhonha and Vale do Mucuri regions. The results pointed to a micro and mesoregional inequality in the distribution of agricultural activities in the mining territory that seems to reflect the incomplete agricultural modernization process that occurred in the state in the $70 \mathrm{~s}$ and $80 \mathrm{~s}$.
\end{abstract}

Key words: spatial analysis, agricultural culture, space clusters, microregion.

Desigualdades na concentração espacial de culturas agrícolas entre as micro e mesorregiões de Minas Gerais, Brasil

RESUMO: O presente trabalho tem por objetivo mapear e estimar a autocorrelação espacial das culturas agricolas de café, milho, soja, cana-de-açúcar e feijão no estado de Minas Gerais e analisadas no período de 2011 a 2015. Os dados de área plantada foram obtidos do Levantamento Sistemático da Produção Agrícola - IBGE. Empregou-se o modelo de Análise Exploratória de Dados Espacial com cálculo da autocorrelação espacial por meio do Índice de Moran Global e Local. Constatou-se autocorreção espacial significativa em todas as culturas estudadas (p-valor <0,05). As regiões com maior concentração de área plantada estão localizadas na porção oeste do estado. As regiões de plantio menos expressivas foram dos municipios localizados na região do Jequitinhonha e Vale do Mucuri. Os resultados apontam para uma desigualdade micro e mesorregional da distribuição das atividades agrícolas no território mineiro, que parece refletir o processo de modernização agrícola incompleta que ocorreu no estado nas décadas de 70 e 80.

Palavras-chave: análise espacial, cultura agrícola, clusters espaciais, microrregião.

\section{INTRODUCTION}

The development of the agricultural sector in Brazil can be considered recent when analyzing the country's economic growth processes that were initiated in the 1950s and 1960s. Back then, there were strong incentives toward industrialization and urbanization in the cities, and the agricultural sector was not a government priority. Domestic supply was largely provided by imports, and the technology for developing agriculture was insufficient in areas that were considered less favorable for planting crops (EMBRAPA, 2018).

From the 1970s onward, the growth of this sector started to become more evident with the spread of the movement known as the Green Revolution, which widely spread the use of agricultural technological packages to increase productivity (CHONCHOL, 2005). In Brazil, the Cerrado biome, which was previously considered unsuitable for agricultural development owing to the edaphic conditions of the soil, benefited from the technological packages in the 1970s, which resulted in soil correction, mechanical irrigation techniques, and the genetic improvement of seeds. The Cerrado Development Program (POLOCENTRO) initiated in 1975, and the Japan-Brazil Agricultural Cooperation Program for the Development of the Cerrado (PROCEDER) established in 1979, are noteworthy for having significantly increased the productivity 
and competitiveness of the Cerrado regions in Brazil (BROGGIO et al., 1999; ORTEGA et al., 2014).

The modernization of national agriculture was started in the 1970s in order to ensure internal supply. The increased productivity in pasture areas, financial and technological incentives for agricultural development in the Cerrado biome, and advances in biotechnology all contributed to the implementation of shorter production cycles, the intensification of production centers in the country (VIEIRA FILHO et al., 2016), increased agricultural production, and the rapid expansion of cultivated areas (JARDIM et al., 2009). The 2017 Agricultural Census showed that a part of the productivity performance of some agricultural crops was related to the use of technologies and mechanization in the field, recording a $49.9 \%$ increase in the tractor fleet over that recorded in the 2006 Agricultural Census, and a 72.1\% increase in the use of sowing/planting machines, harvesters, and fertilizers (FUNDAÇÃO JOÃO PINHEIRO, 2019).

Agricultural development in Minas Gerais has followed the national agrarian development process. The importance of Minas Gerais in the national scenario has increased, as reported in a study by SILVA et al. (2012), who analyzed agricultural production in the state between 1996 and 2006. Those authors identified a rupture of the colonial monoculture structures, the implementation of machinery and inputs in the field, and increased participation of the state in the national Gross Domestic Product of Agribusiness (GDP-Agro) from $9.5 \%$ in 2001 to $12.8 \%$ in 2010 .

The agricultural sector in Minas Gerais reflects the national conjuncture and takes a prominent role in the state, with a $4.92 \%$ increase in annual income in 2018. This profile was directly related to the good performances of coffee, soybean, and corn crops (CEPEA, 2018).

Another important point contributing to the development of the agricultural sector in Minas Gerais was the inequality in investments, technological incorporations, and field modernizations in many areas, due mainly to the economic and social heterogeneity of each region. (DE ANDRADE BASTOS \& GOMES, 2011; CAMPOS et al., 2014). DEANDRADE BASTOS \& GOMES (2011) reported a tendency for the relocation of noncompetitive agricultural activities with high production costs to more productive areas of the state as a means of economic survival. This implies that the process of spatial rearrangement is mostly concentrated in the western region of the state, in Cerrado biomes and areas previously used for traditional cultures.
This highlights the need for a better understanding of the spatial dynamics of the most important agricultural crops in the state, using geoprocessing tools to support the planning, data survey, and organization of land use and occupation in order to provide relevant agricultural and environmental management information (HAMADA et al., 2007). The objective of this study was to characterize, map, and estimate the spatial autocorrelation of relevant agricultural crops for the state of Minas Gerais in the period from 2011 to 2015; thereby, identifying possible factors that contributed to the spatial dynamics.

\section{MATERIALS AND METHODS}

\section{Data source}

Data on the planted area (in hectares) were obtained from the Instituto Brasileiro de Geografia e Estatistica (IBGE; Brazilian Institute of Geography and Statistics) Municipal Agricultural Production (PAM). The choice of agricultural crops was based on their contribution to the Gross Domestic Product of Agribusiness (GDP-Agro) of Minas Gerais in the year 2016 (CEPEA, 2016). Therefore, the analysis covered data on the following crops: coffee, corn, soybean, sugarcane, and beans (grains).

\section{Exploratory spatial data analysis \\ Exploratory spatial data analysis (ESDA)} techniques are important tools for describing and analyzing the spatial distribution pattern of a variable and for identifying atypical behaviors, such as spatial outliers and clusters. An important part of this analysis was the possibility of extracting global and local spatial autocorrelation measures and estimating their magnitude among the areas. Therefore, it was necessary to define the neighborhood criteria and to develop a spatial proximity matrix or spatial weights matrix or simply matrix [Wij] (CÂMARA et al., 2010; LUZARDO et al., 2017).

\section{Spatial weights matrix}

Determination of a spatial autocorrelation structure demands a notion of the spatial proximity between pairs of polygons (areas), being calculated through the matrix of spatial weights that represent the degree of connection between regions according to some proximity criterion. Therefore, the connection between pointed in the matrix [Wij] (where [W] represents the weight, [i] the row, and [j] the column). The proximity criteria can be the distance (established by the analyst himself), the contiguity/adjacency in 
which [Wij] = 1 if [Ai] shares a common side with [Aj], or $[\mathrm{Wij}]=0$ if $[\mathrm{Ai}]$ did not shares a common side with [Aj], and the neighborhood criterion where $[\mathrm{Wij}]=1$ if [Aj] is one of the [p] closest neighbors to [Ai] and in the opposite case, are not neighbors [Wij] $=0$. This binary model required symmetry between the two sides of the matrix, since the elements of the main matrix diagonal will be equal to zero (LUZARDO et al., 2017).

\section{Global Moran's and LISA index}

After establishing the spatial structure using the matrix [Wij], it is necessary to test the spatial dependence, which is how much the value of a variable in a space region depends on the value of the same variable in neighboring regions. The function used is the spatial autocorrelation, which can be expressed through the global Moran's index (I) (CÂMARA et al., 2010).

Since there is a large quantity of area numbers for this analysis, the behavior of the variable is likely to have different spatial association regimes. Thus, the local Moran's I identified where there is a stronger special dependency, resulting in a specific value for each area through the following equation eq.(1) (CÂMARA et al., 2010):

$$
I=\frac{\sum_{i=1}^{n} \sum_{j=1}^{n} w_{i j}\left(z_{i}-\bar{z}\right)\left(z_{j}\right.}{\sum_{i=1}^{n}\left(z_{i}-\bar{z}\right)^{2}}
$$

$\mathrm{n}=$ number of areas

$\mathrm{zi}=$ value of the attribute considered in area $\mathrm{i}$

$\mathrm{z}=$ mean value of attribute in the study region

$w i j=$ elements of the normalized spatial proximity matrix, which expresses the spatial neighborhood structure of the data

The significance of the values of the Global and Local Moran's index were calculated using the Monte Carlo simulation method where the value of the statistic $I$ of the other areas is randomly exchanged and for each permutation the value of the Index were calculated (pseudodistribution) 999 permutations were used. Values that are too high or too low in each permutation are considered of interest and a p-value (pseudo-significance) can be estimated for Moran's statistic $I$ in relation to the set of values obtained in all permutations. A thematic map can be made from the significant values differentiating it from the other regions (LUZARDO et al., 2017).

A Moran's $I$ spread diagram compares normalized elements of an area with the mean values of the neighbors, in a two-dimensional graph subdivided into four different spatial patterns. Spatial associations considered positive are located in the high-high (HH) quadrants when the variable value of each polygon and the mean value of the neighboring polygons are greater than the global mean. Low-low (LL) quadrants mean the opposite condition. The standard high-low (HL) quadrant presents negative spatial association when the variable value of each polygon is above the global mean (high) and the mean value in the neighbors is below the mean (low). The opposite condition is represented in the upper-left low-high (LH) quadrant (LUZARDO et al., 2017).

The variable density of agricultural cultivation (DAC) was obtained by dividing the planted area (or area intended for planting) of each crop in the municipality, microregion, and mesoregion (in hectares) by the territorial area of the municipality, microregion, and mesoregion (also in hectares), and then multiplying the result by 100 . The calculation of the median between the years 2011 and 2015 resulted in the $\mathrm{DAC}_{\mathrm{M}}$ study variable.

\section{RESULTS AND DISCUSSION}

The agricultural crops studied represented a mean of $8.07 \%$ of the territorial state area in the period from 2011 to 2015. According to the global Moran's I, all cultures presented positive spatial autocorrelation, with $\mathrm{p}<0.05$ by the significance test (Table 1), showing that municipalities with a high $\mathrm{DAC}_{\mathrm{M}}$ value were close to municipalities with a high density as well; alternatively, municipalities with a low $\mathrm{DAC}_{M}$ value were surrounded by other municipalities with low $\mathrm{DAC}_{\mathrm{M}}$ values.

Local spatial association indicators showed the presence of the four spatial regimes, with the largest number of municipalities being located in the $\mathrm{HH}$ and LL $\mathrm{p}$ ositive association quadrants for all studied cultures. Corn was the crop with the largest number of municipalities in the HH quadrant $(\mathrm{n}=$ $209)$, followed by beans $(n=181)$ and coffee $(n=$ 171). These three crops (corn, beans, and coffee) represent important agricultural activities in Minas Gerais (Table 1).

Figure 1 presents the local Moran's I significance maps of the municipalities located in the $\mathrm{HH}$ and LL quadrants that had statistical significance $(p<0.05)$. Only corn had significant values in the LL quadrant in the municipalities of the Mucuri Valley region, which is in the northeastern part of the state. This pattern was expected, since the Mucuri Valley was the second region that allocated less areas for corn cultivation in the period studied $(0.21 \%)$.

Municipalities with significant soybean, coffee, sugarcane, and bean crops were located in the 
Table 1 - Territorial occupation, Global Moran's and LISA index of density of agricultural cultivation (DAC $\mathrm{M}_{\mathrm{M}}$ ), by type of crop in the period 2011 to 2015 - Minas Gerais.

\begin{tabular}{|c|c|c|c|c|c|c|c|c|}
\hline & & $\begin{array}{l}\text { I Global } \\
\text { Moran }\end{array}$ & & & & & LISA--. & \\
\hline $\begin{array}{l}\text { Agricultural } \\
\text { cultivation }\end{array}$ & $\begin{array}{c}\% \text { planted } \\
\text { area }\end{array}$ & $\begin{array}{l}\text { I Moran } \\
\left(\mathrm{DAC}_{\mathrm{M}}\right)^{*}\end{array}$ & $\mathrm{HH}$ & LL & HL & LH & $\begin{array}{c}\text { significant } \\
\text { municipalities }\end{array}$ & $\begin{array}{c}\text { non-significant } \\
\text { municipalities }\end{array}$ \\
\hline Corn & 2.17 & 0.486 & 209 & 480 & 60 & 94 & 109 & 744 \\
\hline Soybean & 1.97 & 0.569 & 85 & 47 & 20 & 31 & 50 & 803 \\
\hline Coffee beans & 1.74 & 0.709 & 171 & 369 & 13 & 60 & 108 & 745 \\
\hline Sugarcane & 1.52 & 0.502 & 76 & 627 & 27 & 36 & 42 & 811 \\
\hline Beans & 0.67 & 0.343 & 181 & 456 & 67 & 120 & 74 & 779 \\
\hline Total & 8.07 & -- & -- & -- & -- & -- & -- & -- \\
\hline
\end{tabular}

$\mathrm{DAC}_{\mathrm{M}}=$ density of agricultural cultivation -median. ${ }^{*}$ P-value $<0.05$ for all Agricultural cultivation. $\mathrm{HH}=($ high-high), LL (low-low), AB (high-low) e BA (low-high).

HH quadrant. Corn crops were mainly concentrated in the municipalities of the Triângulo Mineiro/Alto Paranaíba, southern/southwestern Minas, and western Minas regions (Figure 1), located in the western area of the state. Soybean was the most spatially concentrated crop, grown mainly in the municipalities of the Triângulo Mineiro/Alto Paranaíba and northwestern Minas regions. Owing to the historical specialization in coffee crops reported in the southern/ southwestern and Zona da Mata regions (SOUZA \& PEROBELLI, 2007), the municipalities with positive self-correction values in this study were highlighted in these mesoregions. Local analysis of the sugarcane areas also showed great spatial concentration in the municipalities located in the Triângulo Mineiro/ Alto Paranaíba region bordering with the states of Goiás, Mato Grosso do Sul, and São Paulo, and in some isolated points of the Zona da Mata, southern/ southwestern Minas, and central Mineira regions. Beans (Figure 1) were the most autocorrelated local crop distributed among the regions, with the largest number of significant municipalities reported in the northwestern region of Minas, showing the importance of this region in legume cultivation. The southern/southwestern, Campos das Vertentes, Zona da Mata, western, and Triângulo Mineiro/Alto Paranaíba regions also presented a significant number of municipalities for bean cultivation, albeit in much smaller proportions.

Therefore, there was a greater spatial concentration of crops in the northwestern, Triângulo Mineiro/Alto Paranaíba, and southern/southwestern mesoregions in the western area of the state, in addition to some municipalities in Zona da Mata situated to the east of the state. Such knowledge of the regional heterogeneity and of some of the historical processes of agricultural development that occurred in the state of Minas Gerais allows for a better understanding of the concentration and spatial dispersion of the crops analyzed in this study. Some considerations related to each of these five agricultural crops are reported below.

\section{Corn}

In this study, corn-planted areas represented the largest proportion of plantations, occupying more than 1.2 million hectares and approximately $2.17 \%$ of the state area in the period studied (Table 1). According to GARCIA et al. (2006), corn is one of the most traditional products of Minas Gerais agriculture, and its growth has been associated with increased productivity over the years in response to market demands and the possibility of its use in different products, such as food for human consumption and animal feed. Therefore, corn is a relevant temporary crop in high and low income countries. In Minas Gerais, the growth of corn cultivation was due to its increased yield (GARCIA et al., 2006) mainly in the western area; that is, in the regions of Triângulo Mineiro/Alto Paranaíba, Campos das Vertentes, and southern/southwestern Minas Gerais.

GARCIA et al. (2006) reported that the spatial concentration of corn in these regions was favored by the ecological conditions (climate and topography), the proximity to consumer markets and production outlets, such as São Paulo and the midwestern region of Brazil after the opening of the Belo Horizonte-Brasília highway (MEYER \& BRAGA, 1998), and/or benefits from Cerrado development programs. In other regions like Central Mineira, Vale do Rio Doce, Vale do Mucuri, and 


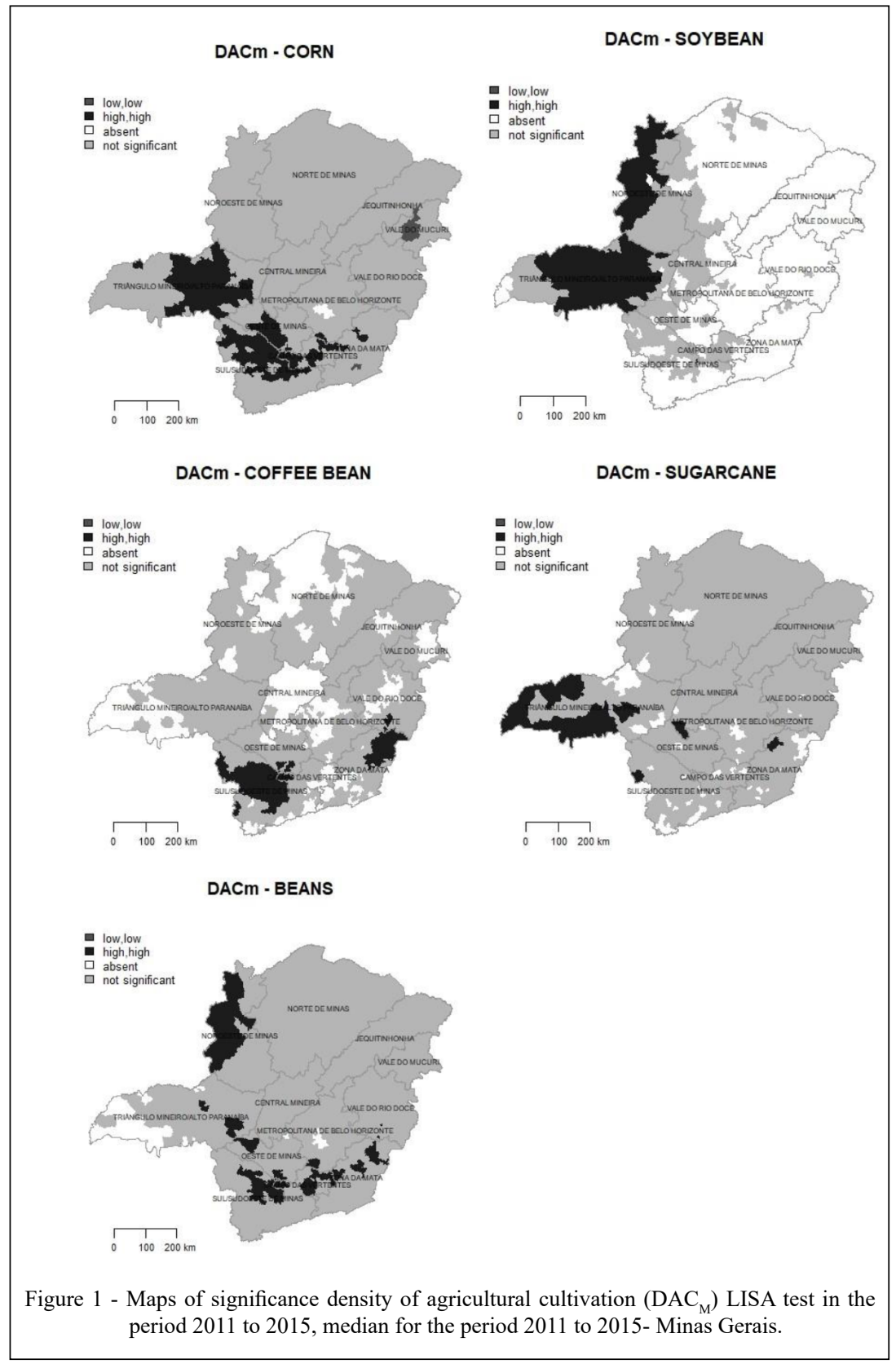

Jequitinhonha, there was a significant reduction in the planted area, as characterized by lower agricultural yields (GARCIA et al., 2006).

\section{Soybean}

With regard to soybean cultivation, the soil in Minas Gerais has very specific characteristics derived from long years of genetic improvement and transgenic research to adapt the crop to the soil conditions of the Cerrado biome (ZITO et al., 2011). Government and partner institution initiatives, such as the Minas Gerais Agricultural Research Corporation (EPAMIG), Brazilian Agricultural Research Corporation (EMBRAPA), Federal University of Viçosa (UFV), Universidade Federal de Lavras (UFLA), and Japan International Cooperation Agency (JICA), contributed with agricultural experimentation research to enable the cultivation of this legume in 
a tropical climate, mainly in the Triângulo Mineiro/ Alto Paranaíba region. These efforts expanded this crop in the region through the incorporation of technology and agricultural mechanization (ZITO et al., 2011; ORTEGA et al., 2014).

Since the 1990s, biotechnology has contributed significantly to the research and introduction of new characteristics in soybean cultivation (ZITO et al., 2011). The present study showed that the Triângulo Mineiro/Alto Paranaíba and northwestern mesoregions had the largest $\mathrm{DAC}_{\mathrm{M}}$ values of $6.99 \%$ and $6.76 \%$ of territorial occupation with soybean cultivation, respectively.

The consolidation of crops in the Cerrado region(Triângulo Mineiro/Alto Paranaíba), previously considered inappropriate for some agricultural crops, was seen mainly after the 1980s. The topography of the site, which is characterized by plateaus (an extensive range of flat areas), facilitates the use of modern technologies and agricultural machinery to allow irrigation, soil correction, chemical fertilizer use, and mechanization, placing the region as one of the main agricultural poles of the state (BROGGIO et al., 1999). Econometric studies by SOUZA \& PEROBELLI (2008) have already identified the unequal distribution of soybean cultures among the Brazilian mesoregions.

\section{Coffee (grains)}

The $\mathrm{DAC}_{\mathrm{M}}$ of coffee, the main product of Minas Gerais agribusiness, was spatially distributed mostly in the southern/southwestern mesoregions, with $8.75 \%$ of the area intended for crops, followed by $5.73 \%$ in Zona da Mata and $3.19 \%$ in the western region. According to the IBGE (2016), the spatiality of this culture was related to natural characteristics as well as socioeconomic and political processes that redirected the forms of land appropriation and use in the national territory. Thus, municipalities in the southern/southwestern region stood out in the production of Arabica coffee (the most produced type in the state) because this species is adapted to highaltitude regions with mild annual temperatures of between $18{ }^{\circ} \mathrm{C}$ and $23{ }^{\circ} \mathrm{C}$. In addition, the region has great storage capacity for the quantity produced, a high level of agricultural automation, and geographical advantage for production flow owing to its proximity to the state of São Paulo; and consequently, to the port of Santos (IBGE, 2016).

Zona da Mata was the second largest region with coffee areas in Minas Gerais, corroborating the findings of other studies (DE ANDRADE BASTOS \& GOMES, 2011; IBGE, 2016). This region is characterized by a hilly relief and sub-humid climate, with agricultural production being concentrated in the fertile valleys, which in turn incurs higher production costs than those of other regions in Triângulo Mineiro (DE ANDRADE BASTOS \& GOMES, 2011). It is nonetheless an important Arabica coffee-producing region. The largest $\mathrm{DAC}_{\mathrm{M}}$ was seen in the Manhuaçu microregion (Table 2), with $23.23 \%$ of the area used for coffee production. These data are also corroborated by SANTOS et al. (2008) and SOUZA \& PEROBELLI, (2007), who reported that this region has a greater structure for production processing and commercialization.

\section{Sugarcane}

Sugarcane cultivation in Minas Gerais was strongly concentrated in the municipalities in the Triângulo Mineiro mesoregion, which had approximately $7 \%$ of its territorial area planted with this crop. This was followed by the central region of the state, with $1.76 \%$. This information is corroborated by VIDIGAL et al. (2011), who studied the spatial distribution of sugarcane in Minas Gerais and reported a significant spatial autocorrelation between the years 1990 and 2007. According to SIQUEIRA \& CASTRO JUNIOR, (2013), sugarcane production in Minas Gerais had greater economic importance after the 1990s and was influenced mainly by increased ethanol production and consumption.

The concentration of sugarcane production in the Triângulo Mineiro and northwestern regions was also favored by state government investments, with the creation of new sugar and alcohol plants in these regions. The main determinants of sugarcane agroindustry location were reported to be productivity, land concentration, leasing, and access to water resources, as these factors were strongly correlated with the presence of sugarcane agroindustry in these regions (SIQUEIRA \& CASTRO JUNIOR, 2013).

\section{Beans (grains)}

This study revealed that beans were the fifth crop in terms of area planted in Minas Gerais, being basically concentrated in the Campos das Vertentes and northwestern mesoregions, which was corroborated by other studies (WANDER et al., 2014). Beans are one of the main components of the Brazilian food culture, representing one of the greatest sources of vegetable protein in the diet. Unlike other commodities, beans are mostly produced on family farms in Brazil (WANDER et al., 2014).

Although, Minas Gerais is the second largest national producer of beans, the planted areas have been reduced owing to the difficulties encountered in the water management of this crop. The bean crop is very sensitive to both water scarcity and 
Table 2 - Five microregions with higher density of agricultural cultivation (DAC $\mathrm{M}_{\mathrm{M}}$ ), by type of crop in the period 2011 to 2015 , median for the period 2011 to 2015 - Minas Gerais.

\begin{tabular}{|c|c|c|c|}
\hline $\begin{array}{l}\text { Agricultural } \\
\text { cultivation }\end{array}$ & $\mathrm{DAC}_{\mathrm{M}}$ & microregions & mesoregions \\
\hline \multirow[t]{5}{*}{ CORN } & 8.06 & Uberaba & Triângulo Mineiro/Alto Paranaíba \\
\hline & 7.79 & Araxá & Triângulo Mineiro/Alto Paranaíba \\
\hline & 7.42 & Varginha & Sul/Sudoeste de Minas \\
\hline & 6.14 & Alfenas & Sul/Sudoeste de Minas \\
\hline & 6.06 & Campo Belo & Oeste de Minas \\
\hline \multirow{5}{*}{ SOYBEAN } & 14.85 & Uberaba & Triângulo Mineiro/Alto Paranaíba \\
\hline & 9.54 & Uberlândia & Triângulo Mineiro/Alto Paranaíba \\
\hline & 9.35 & Unaí & Noroeste de Minas \\
\hline & 8.67 & Araxá & Noroeste de Minas \\
\hline & 6.86 & Patrocínio & Triângulo Mineiro/Alto Paranaíba \\
\hline \multirow{5}{*}{ COFFEE BEANS } & 23.23 & Manhuaçu & Zona da Mata \\
\hline & 17.53 & Varginha & Sul/Sudoeste de Minas \\
\hline & 15.43 & São Sebastião do Paraíso & Sul/Sudoeste de Minas \\
\hline & 13.28 & Alfenas & Sul/Sudoeste de Minas \\
\hline & 10.78 & Santa Rita do Sapucaí & Sul/Sudoeste de Minas \\
\hline \multirow{5}{*}{ SUGARCANE } & 17.82 & Uberaba & Triângulo Mineiro/Alto Paranaíba \\
\hline & 11.66 & Frutal & Triângulo Mineiro/Alto Paranaíba \\
\hline & 7.99 & Ituiutaba & Triângulo Mineiro/Alto Paranaíba \\
\hline & 5.22 & Uberlândia & Triângulo Mineiro/Alto Paranaíba \\
\hline & 5.05 & Ponte Nova & Zona da Mata \\
\hline \multirow{5}{*}{ BEANS } & 2.72 & Unaí & Noroeste de Minas \\
\hline & 2.57 & Alfenas & Sul/Sudoeste de Minas \\
\hline & 2.55 & São João Del Rei & Campo das Vertentes \\
\hline & 2.34 & Viçosa & Zona da Mata \\
\hline & 2.34 & Campo Belo & Oeste de Minas \\
\hline
\end{tabular}

excess. Thus, higher yields tend to be concentrated in regions with a greater agricultural infrastructure for automated irrigation (SILVA et al., 2011).

\section{Aspects of agricultural development}

These considerations about the five agricultural crops analyzed in this study show relevant aspects that may have contributed to the regional inequalities in terms of agricultural development. The process of agricultural modernization in Minas Gerais reflects to some extent the development model observed in Brazil.
The initial evidence of agricultural modernization was related to the industrialization process promoted by the military government after the 1970s. Before that period, the agricultural sector was considered an environment of technological backwardness, low productivity, and little diversity. However, it is now the target of a government expansion policy aiming modernization and industrialization. Thus, areas considered more suitable to receiving what was conventionally called a "technological package" had greater financial incentives, scientific research, and rural technical 
assistance to increase productivity (MEYER \& BRAGA, 1998; SILVA et al., 2005).

The importation of this model into Minas Gerais was mainly due to a partnership between Brazil and the United States that created the Association of Credit and Rural Assistance (ACAR), a pioneer project in rural extension, which was replaced shortly after by the Technical Support and Rural Extension Company of the State of Minas Gerais. This institution disseminated technical knowledge to increase productivity along the lines of the Green Revolution, fostering rural credit, inputs, agricultural mechanization, and the uses of fertilizers and genetically modified seeds (RAMBO et al., 2015).

However, SILVA et al. (2005) stated that this process contributed to the retention of inequalities in the field, since greater land ownership allowed greater access to subsidized rural credit; and consequently, greater investment and productivity gains in agricultural crops of greater financial interest, such as commodities. In addition, state and national governments invested in scientific research to improve production. SILVA et al. (2005) analyzed the main components of the agricultural dynamics in Minas Gerais and revealed that the spatial distribution of those dynamics showed an east-west pattern.

This present study, which characterized the space allocated for important agricultural crops in Minas Gerais and corroborates literature findings, concluded that the agricultural modernization promoted by the state was incomplete and late, which may have contributed to the differences in regional development still visible and present in Minas Gerais.

\section{CONCLUSION}

The results of this study identified the regions in the state of Minas Gerais that represent spatial clusters of the main agricultural crops produced between 2011 and 2015 and the regions where the planted area was less important. A great spatial concentration of agricultural activity in the micro- and mesoregions was demonstrated mainly in municipalities located in the western area of the state (e.g., the Triângulo Mineiro/Alto Paranaíba, northwestern, and southern/southwestern regions) and in the eastern area (specifically Zona da Mata). However, the state also presented locations where agricultural activity was dispersed or not important, such as the northern, Jequitinhonha, and Mucuri Valley mesoregions.

This scenario showed the unequal way in which the process of agricultural modernization was implemented in the state of Minas Gerais. An attempt was also made in this study to identify the possible factors that may have contributed to the inequalities presented. The main factors described in the literature are the inclusion of technological packages in regions considered more favorable and profitable, and the rural credit distribution policy in the state.

Thus, further space-time distribution studies are needed to identify regions of productive concentration and those that require greater investment of resources and rural technical assistance. Such studies should consider the natural aspects and agricultural characteristics of each region in order to favor socioeconomic development in other parts of the state, with the ultimate goal being to support the planning and decision-making processes of the public or private agents involved in the management of agricultural activities in Minas Gerais.

\section{ACKNOWLEDGEMENTS}

This study was financed in part by the Coordenação de Aperfeiçoamento de Pessoal de Nível Superior - Brasil (CAPES) - Finance Code 001

\section{DECLARATION OF CONFLICT OF INTEREST}

The authors declare no conflict of interest. The founding sponsors had no role in the design of the study; in the collection, analyses, or interpretation of data; in the writing of the manuscript, and in the decision to publish the results.

\section{AUTHORS' CONTRIBUTIONS}

ECR and RT conceived and performed analyzes. ECR and ALM prepared and organized the draft of the manuscript. All authors critically reviewed the manuscript and approved the final version.

\section{REFERENCES}

BROGGIO, C. et al. A dinâmica territorial da Cafeicultura brasileira: dois sistemas de produção em Minas gerais. Revista Território, year IV, n6, p.73-91, 1999. Available from: <http:// www.revistaterritorio.com.br/pdf/06_7_broggio_droulers_ grandjean.pdf $>$. Accessed: Apr. 02, 2018.

CÂMARA, G. et al. Análise espacial de áreas In: Druck, S.; Carvalho, M.S.; Câmara, G.; Monteiro, A.V.M. Análise Espacial de Dados Geográficos. Brasília: EMBRAPA, 2004.

CAMPOS, S.A.C. et al. Trajetória de modernização da agropecuária mineira no período de 1996 a 2006. Economia Aplicada, v.18, n 4, p.717-739, 2017. Available from: <http://www.scielo.br/scielo. php?script $=$ sci_ arttext\&pid $=$ S1413-80502014000400007 $>$. Accessed: Aug. 15, 2016. doi: 10.1590/1413-8050/ea115282.

CEPEA, Centro de Estudos Avançados em Economia Aplicada. Relatório Análise do PIB-renda setembro 2018. Piracicaba, 2018. 16p. Available from: <https:// www.cepea.esalq.usp.br/br/ pib-do-agronegocio-brasileiro.aspx $>$. Accessed: Dec. 10, 2018.

CEPEA, Centro de Estudos Avançados em Economia Aplicada. Relatório PIB do Agronegócio Estado de Minas Gerais. Piracicaba, 2016. 22p. Available from: <https://www.cepea. 
esalq.usp.br/upload/kceditor/files/Relatorio\%20PIBAGRO $\% 20$ Minas\%20Gerais_novembro.pdf>. Accessed: Jan. 23, 2017.

CHONCHOL, J. A Soberania Alimentar. Estudos Avançados, v.19, n.55, p.33-48, 2005. Available from: <http://www scielo.br/scielo.php? script $=$ sci_arttext\&pid $=$ S0103-4014200 $5000300003 \& \operatorname{lng}=$ en $\& n r m=$ iso $>$. Accessed: Sep. 02, 2016. doi: 10.1590/S0103-40142005000300003.

DE ANDRADE BASTOS, S.Q.; GOMES, J.E. Dinâmica da agricultura no Estado de Minas Gerais. Análise estruturaldiferencial para o período 1994-2008. RURIS, v.5, n.2, p.45-75, 2011. Available from: < https://www.ifch.unicamp.br/ojs/index. php/ruris/article/view/1463>. Accessed: Apr. 02, 2018.

EMBRAPA, Empresa Brasileira de Pesquisa Agropecuária. Visão 2030: O futuro da agricultura brasileira. Brasília, 2018. 212 p.

FUNDAÇÃO JOÃO PINHEIRO. Informativo FJP. Contas Regionais, Censo Agropecuário 2017. n 04. 2019.

GARCIA, J.C. et al. Importância do milho em Minas. Informe Agropecuário, Belo Horizonte, v.32, n.233 p.7-14. 2006. Available from: http://www.epamig.br/download/informe-agropecuario-233-cultivo-domilho-no-sistema-plantio-direto-2006/>. Accessed: Apr. 02, 2018.

HAMADA, E. et al. Introdução ao geoprocessamento: princípios básicos e aplicação. Documentos 67. Jaguariúna: EMBRAPA Meio Ambiente, 2007.52p. Available from: <http://www.cnpma.embrapa. br/download/documentos_67.pdf>. Accessed: Jan. 15, 2017.

IBGE, Instituto Brasileiro de Geografia e Estatística. A Geografia do Café. Coordenação de Geografia. Rio de Janeiro, 2016. 136p.

JARDIM, I.C.S.F. et al. Resíduos de agrotóxicos em alimentos: uma preocupação ambiental global - um enfoque às maçãs Química Nova, v.32, n.4, p.996-1012, 2009. Available from: $<$ http://www.scielo.br/scielo.php? script=sci arttext\&pid $=$ S0100-40422009000400031>. Accessed: Aug. 18, 2016. doi: $10.1590 / \mathrm{S} 0100-40422009000400031$

LUZARDO, A.J.R. et al. Análise espacial exploratória com o emprego do Índice de Moran. GEOgraphia, vol. 19, n.40, p.162179, 2017. Available from: <http://www.geographia.uff.br/index. php/geographia/article/viewFile/673/732>. Accessed: Jan. 03, 2018. doi: 10.22409/GEOgraphia2017.v19i40.a13807.

MEYER, L.F.F.; BRAGA, M.J. O crescimento das desigualdades tecnológicas na agricultura mineira. Revista de Economia e Sociologia Rural, v.32, n. 2, 1988. Available from: < https://www. revistasober.org/article/5da3500d0e8825727bba68e1/pdf/resr-362-59.pdf>. Accessed: Dec. 19, 2019.

ORTEGA, A.C. et al. Transformações Recentes da Produção Agropecuária no Cerrado: Cadeias Produtivas e Clusters na Região do Triângulo Mineiro e Alto Paranaíba. Ensaios FEE, v.35, n.2, p.555-584, 2014 Available from: <https://revistas.fee. tche.br/index.php/ensaios/article/view/2813/3520>. Accessed: Apr. 02, 2018

RAMBO, J.R. et al. Políticas públicas de extensão rural no Brasil contemporâneo: avanços e desafios à construção do desenvolvimento rural sustentável nos estados de Minas Gerais e Mato Grosso. SOBER João Pessoa, 2015. Available from: <http:// www2.fct.unesp.br/nivaldo/Publica\%E7\%F5es-nivaldo/2015/ ATER\%20-\%20MT\%20e\%20MG.pdf>. Accessed: Dec. 19, 2019.
SANTOS, F.A.A. et al. Mudança da composição agrícola em duas regiões de Minas Gerais. Revista de Economia e Sociologia Rural, v.46, n.3, p.579-595, 2008. Available from: <http://www.scielo.br/ scielo.php?script $=$ sci arttext\&pid=S0103-20032008000300001>. Accessed: Apr. 25, 2018. doi:10.1590/S0103-20032008000300001.

SILVA, E. et al. Viabilidade financeira da produção de feijão em sistema automatizado de irrigação por miniaspersão. Organizações Rurais e Agroindústria, v.13, n.2, p.290-302, 2011. Available from: $<$ http://www. redalyc.org/articulo.oa?id=87819763009>. Accessed: Apr. 22, 2018.

SILVA, G.J.C. et al. Produção agropecuária em municípios de Minas Gerais (1996-2006): padrões de distribuição, especialização e associação espacial. Revista de Economia e Sociologia Rural, v.50, n.2, p.333-349, 2012. Available from: <http://www.scielo.br/ scielo.php?script $=$ sci arttext\&pid $=$ S0103-20032012000200008 $>$. Accessed: Jan. 23, 2017. doi: 10.1590/S0103-20032012000200008.

SILVA, H. et al. Dinâmica agropecuária e urbanização: uma análise multivariada para Minas Gerais, 1995-2000. In: XXXII Encontro Nacional de Economia. Natal. 2005 Available from: $<$ http://www.anpec. org.br/encontro2005/artigos/A05A140.pdf>. Accessed: Dec. 19, 2019.

SIQUEIRA,P.H.DE.L.;CASTROJUNIOR,L.G.DE.Determinantes da localização da agroindústria canavieira nos municípios de Minas Gerais. Revista de Economia e Sociologia Rural, v. 51, n. 2, p.309-330, 2013 Available from: <http://www.scielo. br/scielo.php?pid=S0103-20032013000200006\&script $=$ sci abstract\&tlng=pt $>$. Accessed: Apr. 22, 2018. doi:10.1590/S010320032013000200006

SOUZA, M.C.; PEROBELLI, F.S. Análise da distribuição territorial da sojicultura no Brasil: 1991-2003. Revista Econômica do Nordeste, v.39 p.46-65, 2008 Available from: <https://ren. emnuvens.com.br/ren/article/view/450>. Accessed: Dec. 04, 2019.

SOUZA, R.M.; PEROBELLI, F.S. Diagnóstico espacial da concentração produtiva do café no Brasil, no período de 1991 a 2003, Revista de Economia e Agronegócio. v.5, n.3., p. 353378. 2007. Available from: <https://ageconsearch.umn.edu/ record/54591/>. Accessed: Dec. 04, 2019. doi:10.25070/rea. v5i3.109.

VIDIGAL, V.G. et al. Análise espacial da produtividade da canade-açúcar em Minas Gerais, 1990 a 2007. Revista de Economia e Administração, v.10, n.2, p.241-261, 2011. Available from: $<$ http://www.spell.org.br/documentos/ver/5044/analise-espacialda-produtividade-da-canade--ac--->. Accessed: Apr. 22, 2018.

VIEIRA FILHO, J.E.R. et al. Agricultura, transformação produtiva e sustentabilidade. Brasília, IPEA, 2016.391p.

ZITO, R.K. et al. Soja em Minas Gerais. Informe Agropecuário, Belo Horizonte, v.32 (260), p16-21. 2011. Available from: <http:// www.epamig.br/download/informe-agropecuario-260-tecnologiaspara-o-cerrado-mineiro-2011/>. Accessed: Apr. 02, 2018.

WANDER, A.E. et al. Rentabilidade da produção de feijão no Brasil (in): Sustentabilidade e sustentação da produção de alimentos no Brasil: O desafio da rentabilidade na produção. Centro de Gestão e Estudos Estratégicos. Brasília: EMBRAPA. v.2, 2014. 228p. 